\title{
THE ADMINISTRATION OF THE OIL AND GAS CONSERVATION ACT IN ALBERTA
}

G. W. GOVIER*

This paper is the text of a speech delivered to the Canadian Petroleum Law Foundation, Seventh Annual Research Seminar in Oil and Gas Law, Jasper, Alberta, May 29 to June 1, 1968. The author outlines the objectives, functions and typical proceurures of The Oil and Gas Conservation Board.

It is indeed a great pleasure for me to have been invited to speak to you on this occasion. I know of the good work performed by the Canadian Petroleum Law Foundation over many years and I am glad that you have chosen the subject of conservation for discussion this year.

I have been asked to help set the stage for this year's program and, therefore, I would like to highlight the authority of the Oil and Gas Conservation Board and to point out the way in which this is exercised.

First let me say a little about oil and gas conservation in general. The present concepts of conservation have been developed over the past 35 years. They originated in Texas and Oklahoma following the discovery of substantial oil fields and the resultant overproduction, waste and collapse of prices. Initially regulations were instituted to protect correlative rights and eliminate surface waste. With improved technical knowledge of the behaviour of oil and gas in underground reservoirs came the development of the idea of maximum recovery consistent with reasonable economy. Today measures to encourage or require enhanced recovery are a most important part of oil and gas conservation.

The oil and gas industry is made up of rugged individualists who strongly favour free enterprise, but, on the whole, conservation measures enforced by state or provincial legislation have been welcomed and supported by industry because of the stabilizing effect these have had on the industry and because of the increases in recovery which have been brought about without sacrificing the competitive position of individual companies.

The development of oil and gas conservation in Alberta somewhat parallels that in the United States although we probably always have had more emphasis on the elimination of waste and the desirability of maximum recovery. The Turner Valley Conservation Act of $1932^{\prime}$ provided measures for conserving gas and reservoir energy in the Turner Valley Field and the Turner Valley Conservation Board created at that time was the lineal ancestor of the present Oil and Gas Conservation Board. Conservation concepts and legislation gradually developed over the years and with the establishment of the Petroleum and Natural Gas Conservation Board there was a fairly adequate set-up by 1947 when the famous Leduc discovery was made. The legislation and regulations under it have been continually reviewed and kept up to date. Last year there was a complete review, with the co-operation of in-

* Chairman, Alberta Oil and Gas Conservation Board.

1 S.A. 1932, c. 6. 
dustry, of all regulations. This year there will be a comprehensive review of The Oil and Gas Conservation Act.

The Alberta Oil and Gas Conservation Act sets out three main conservation objectives, to ensure:

1. conservation and prevention of waste of oil and gas resources,

2. safe and efficient practices in locating, spacing, drilling and operation of wells, and

3. that mineral owners are afforded every opportunity to recover their minerals. ${ }^{2}$

The Oil and Gas Conservation Act creates the Oil and Gas Conservation Board which is a body corporate, an administrative tribunal, consisting of three appointed members. The Act gives responsibility and authority to the Board in the administration of Alberta's conservation policy.

The Oil and Gas Conservation Board has its main office in Calgary and has area offices in Edmonton, Medicine Hat, Turner Valley, Drayton Valley and Red Deer. It has a staff of 270 and about 60 of these are professional personnel. It operates on a budget of two and three-quarter million dollars, financed on a 50-50 basis by government and industry, equivalent to a unit cost of $2 / 3$ cent per barrel of production.

Two other Acts also are administered by the Oil and Gas Conservation Board. These are The Gas Resources Preservation Act $^{3}$ and The Turner Valley Unit Operations Act." The former Act charges the Board with the administration of gas export in accordance with government policy, while the latter Act provides for compulsory unit operation in the Turner Valley Field under Board administration.

I would like to comment now on the way in which the Board discharges its responsibilities and exercises its authority. First let me say that the Board may act either on its own initiative or on application by an interested party. There is a tremendous variation in the complexity of matters considered. This leads to a variation in procedure and the type of report or decision and the provision for reconsideration or appeal. For convenience I have summarized in table form the functions, procedures, reports and appeals I wish to deal with at this time.

You will note that in the first category, comprising the first 10 or 12 items, the Board acts on the advice of its staff or on its own knowledge. It issues a simple authorizing document in the form of a licence, order or approval and all but the licences are circulated to industry. There is provision for application to be made for a review or hearing by the Board and, in most cases, appeal may be made to the Appellate Division of the Supreme Court on matters of law or jurisdiction.

In the second category comprising the next 4 or 5 items covering matters which possibly are controversial, but whose governing principles are pretty well established, the Board publishes notice of the matter and provides an opportunity for the filing of objections. If no objections are received the Board acts on the advice of its staff. However, if an objection is received the Board calls an examiner hearing. Following a decision in this second category a simple document is issued. It may

2 S.A. 1957, c. 63, s. 4.

3 S.A. 1956 , c. 19 .

See appendix, pp. 345 and 346. 
be a letter denying the application, an order or an approval. Ordinarily copies of an order or an approval are circulated to industry. As in the first category, provision is made for a review by a hearing before the Board and appeal may be made to the Appellate Division of the Supreme Court on matters of law or jurisdiction.

Before proceeding to the next group I should mention two matters which are related to public hearings. The Oil and Gas Conservation Act, The Gas Resources Preservation Act and The Turner Valley Unit Operations Act require that certain matters of importance be considered at public hearings. Additionally, the Board frequently decides that the best way to handle a particular matter is by public hearing. About five years ago the Board, with the help of the Canadian Petroleum Association, codified previous practices and established rules of practice to apply to the giving of notice of a hearing, the filing of interventions, and the conduct of the hearing." These rules are relatively simple and reasonably flexible and the Board may vary them. The second matter relates to examiner hearings. The Board has authority under the Act to appoint senior members of its staff as examiners to conduct hearings. The parties involved in the hearing have the right to ask that the hearing be held by the Board members, but to date no such request has been received.

Let us now proceed to the group of functions listed as items 16,17 and 18 in the summary. You will note that the issues here are more involved; they frequently involve correlative rights or complex technical issues but they are still issues with respect to which broad principles have been established. Also included with this group are those matters from the previous group where objections were filed following publication of notice. Normally, all of these are considered by an examiner hearing, but special cases are heard by the Board. Following an examiner hearing the examiners prepare a report which is reviewed by the Board. If the Board has any questions it consults with the examiners and then acts appropriately-usually by the issuance of a simple document, an approval spelling out the conditions of the same. If the matter is of wide interest a brief decision is issued by the Board giving its reasons. This decision is essentially the examiners' report with the Board's views added. There is provision for reconsideration or a rehearing by the Board, as well as for appeal, except in Turner Valley unit applications, to the Appellate Division of the Supreme Court on matters of law or jurisdiction.

The fourth group covering the remaining items on the table, relating to major matters of wide concern to industry, matters involving the application of new policies, matters where the Act requires hearings, and serious matters affecting correlative rights, are dealt with by Board hearing. Following the hearing the Board and its staff study the evidence and the Board acts in accordance with its findings. In certain matters the Board acts only with the approval of the LieutenantGovernor in Council. A brief formal decision or a comprehensive socalled report in the OGCB series is issued and is circulated, often with a copy of the Board's order. An appeal may be made for a review or a rehearing by the Board or an appeal may be made to the Appellate 
Division of the Supreme Court on law or jurisdiction. In the case of matters such as the requiring of recovery operations or of gas conservation an appeal may be made to the Appellate Division on the wider grounds set out in section 119 , subsection (2). With respect to matters requiring the approval of the Lieutenant-Governor in Council an opportunity is usually provided for an appeal to the Executive Council before the Government gives its approval to a Board decision.

This is just a brief summary of the way in which the Board operates; it is not complete in detail but it is illustrative and I hope it will provide a useful background for your considerations.

I know this group has heard all the arguments favouring and against the concept of administrative Boards. I expect you believe there are advantages in certain circumstances but perhaps still are a little uneasy. I don't wish to speak generally but with respect to the kind of matters with which the Board deals-these being specialized and mostly technical -I believe the administrative Board provides a good answer, provided there are proper safeguards and suitable practices to ensure fair treatment.

A Board is not bound by rigid rules of procedure, can deal with simple matters quickly, can operate with a minimum of expense and can adopt court-like procedures with respect to more complex matters and still provide decisions in good time. Assuming its members and staff have the necessary technical qualifications a Board can deal effectively with technical problems and on even terms with technical people. An independent Board can deal alike with all mineral owners, whether they be government or private. Provision for appeal on law or jurisdiction restricts the Board to its proper sphere.

Finally, with respect to the Oil and Gas Conservation Board, I believe the procedures followed do ensure fair treatment to all parties and I hope you also will believe this after your assessment of them. 


\section{APPENDIX \\ OIL AND GAS CONSERVATION BOARD \\ OF ALBERTA \\ SUMMARY OF FUNCTIONS, PROCEDURES, REPORTS AND APPEALS}

\section{ITEM FUNCTION}

1. Issue of well licence

2. Closing area to travel

3. Issue of PSU or Block approvals

4. Exemption from gas measurement

5. Experimental scheme approvals

6. Field designations

7. Pool designations

8. Allowable orders

9. Limitation of surface disposal of water

10. Orders under regulations varying their requirements

11. Gas plant approval

12. Water disposal schemes

13. Suspension of a provision of Act or Regulations in a unit

14. Production from or injection to more than one formation

\section{TYPICAL PROCEDURE}

Board acts on staff advice

Board acts on staff advice

Board acts on staff advice Board acts on staff advice

Board acts on staff advice

Board acts on staff advice

Board acts on staff advice

Board acts on staff advice

Board acts on staff advice

Board acts on staff advice

Board acts on staff advice (in an unusual case, a hearing)

Board acts on staff advice (Publication of notice or examiner hearing if correlative rights involved, or if it is the first scheme in the pool)

Board acts on staff advice (Publication of notice if correlative rights involved)
Publication of notice or examiner hearing

\section{FORM OF DECISION}

Licence issued (or letter of denial)

FH order circulated

Approval issued

GE order circulated

Approval issued

F order circulated

G order circulated

MD or TV order circulated

W order circulated

Misc. order circulated

Circulate approval if granted Letter to applicant if refused

Letter or decision if heard

Misc, order circulated

MU order circulated if granted. Letter of denial. Letter or decision if heard

\section{APPEAL}

Application for review or hearing by Board.

Review or hearing by Board (FH order ordinarily in force for only

2 or 3 days)

Review or hearing by Board.

Appeal to Appellate Division on law or jurisdiction

Review or hearing by Board.

Appeal to Appellate Division on law or jurisdiction

Review or hearing by Board.

Review or hearing by Board. Appeal to Appellate Division on law or jurisdiction 


\section{ITEM}

15. Spacing

16. Shutting in wells for infractions

17. Turner Valley compulsory units

18. Enhanced recovery schemes

19. Gas allowables

20. Requiring enhanced recovery

21. Requiring gas conservation

22. Commercial oil sands scheme

23. Compulsory pooling

24. Common carrier, common purchaser, common processor

25. Removal of gas or propane from province
TYPICAL PROCEDURE

Publication of notice or examiner hearing

Examiner hearing after notice to licensee (Board in extreme cases)

Examiner hearing (Board heard original hearings when the units were created)

Examiner hearing (in case of miscible flood or controversia method-Board hearing)

Annual Board hearing

Board hearing

Board hearing

Board hearing and Order in Counci

Board hearing and Order in Council

Board hearing and Order in Council

Board hearing and Order in Council (minor applications may be advertised instead of heard)

\section{FORM OF DECISION}

SU or GTO order circulated if granted. Letter of denial.

Letter or decision if heard.

$\mathbf{C}$ order and letter to licensee

TVU order circulated

Approval circulated and letter sent to applicant. Letter or

GA orders circulated

Misc. order circulated

GC order circulated

Decision and approval circulated

Decision and $\mathbf{P}$ order circulated

Decision and misc. order circulated

Decision circulated to parties and permit issued

\section{APPEAL}

Review or hearing by Board. Appeal to Appellate Division

on law or jurisdiction

Review or hearing by Board.

Appeal to Appellate Division

on law or jurisdiction

Rehearing by Board

Review or hearing by Board. Appeal to Appellate Division

on law or jurisdiction

Review or hearing by Board.

Appeal to Appellate Division

on law or jurisdiction

Review or hearing by Board. Appeal to Appellate Division on any of the grounds in Sec. 119

Review or hearing by Board. Review by Lieutenant-Governor in Council before OC issued

Review or hearing by Board. Review by Lieutenant-Governor in Council before OC issued

Review or hearing by Board. Review by Lieutenant Governor in council before $O C$ issued. Appeal to Appellate Division on law or jurisdiction

Review or hearing by Board. Review by Lieutenant Governor in council before permit issued 